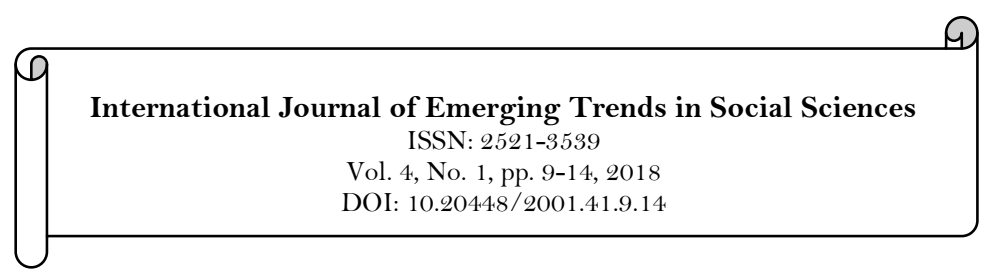

\title{
Sultan Agung's Thought of Javanis Islamic Calender and its Implementation for Javanis Moslem
}

\author{
Muhammad Roy Purwanto ${ }^{1}$ \\ Chusnul Chotimah ${ }^{2}$ \\ Imam Mustofa ${ }^{3}$ \\ ${ }^{1}$ Postgraduate Program of Islamic Studies Faculty, Universitas Islam Indonesia. \\ ${ }^{2}$ IAIN Tulungagung \\ ${ }^{3}$ Institut Agama Islam Negeri Metro Lampung.
}

\begin{abstract}
This article aims to elaborate Sultan Agung's Thought of Javanis Islamic Calender and Its Implementation for Javanis Moslem as guidelines in conducting daily activities. Sultan Agung was the third Sultan of Mataram in Central Java ruling from 1613-1645. A skilled soldier he conquered neighbouring states and expanded and consolidated his kingdom to its greatest territorial and military power. He was the greatest Sultan of Mataram. He sought to rationalize and improve the internal government of his kingdom. He reformed the tax-code and brought the courts and judicial system more in line with Qur'annic precepts. He commissioned the building of the Karta Palace in 1614, the Royal Graveyard of Imogiri, as well as other social and civic structures within the kingdom. One of Sultan Agung's conceptual contribution was Islamic Javanese calendar. It is a blend of Saka calender system with the Hijriyah calender. Saka year system itself is a mix of original acculturation Javanese Hindu-Buddhist. In the culture of Java, Javanis Islamic calendar not only serves as a marker of an event but also serves as a predicted survival and happiness of an arranged marriage or a particular event.
\end{abstract}

\author{
Keywords: \\ Calender \\ Javanis \\ Hijriyah \\ Saka \\ Islam. \\ Licensed: \\ This work is licensed under a \\ Creative Commons Attribution \\ 4.0 License. \\ Publisher: \\ Scientific Publishing Institute
}

\section{Background}

The Sultanate of Mataram (Kesultanan Mataram), an Islamic kingdom on the island of Java, stood in the $17^{\text {th }}$ century (Gamal, 2011). Its origin is a Kadipaten (Duchy) under the Pajang Sultanate, centered on "Bumi Mentaok" given to Ki Ageng Pemanahan as a reward for his services. Its first king was Raden Sutawijaya, a son of Ki Ageng Pemanahan (Brotodiningrat, 1978).

During the reign of the third king, i.e., Mas Rangsang or Sultan Agung Hanyakrakusuma (1613-1645) with a title Sultan Agung (The Great Sultan) Senopati Ing Alaga Sayidin Panatagama, Mataram reached its peak of glory. He tried to unite the island of Java, by subduing Tuban and Pasuruan (1619); Surabaya (1625); and Blambangan (1639). The result of this expansion made the Mataram region be known more widespread. Being agile, intelligent, and obedient in applying Islamic teachings, Sultan Agung made Mataram the largest kingdom on the island of Java at that time. According to the testimony of one European merchant, Balthasar van Eyndhoven, Sultan Agung was a Sultan who could not be underestimated. In 1614, Balthasar with Van Surck went to Mataram to congratulate him on the appointment of the king as the government official. At that time, he thought that the king's age was about 23 years; therefore, the Sultan was assumed to have been born in 1591 (Aminudin, 2005).

One of Sultan Agung's contributions in applying Islam is the application of the Javanese Islamic calendar. In 1633 AD (1555 Saka or 1043 Hijri), Sultan Agung Ngabdurahman Sayidin Panotogomo Molana Mataram (1613-1645) from Mataram abolished the Saka calendar from Java Island, and then created a Javanese calendar that followed the Hijri calendar. However, the number of the year, i.e., 1555, was maintained. Thus, the date of 1 Muharram 1043 Hijri was 1 Muharam 1555 according to Javanese calendar, which fell on Friday Legi 
(Jum'at Legi) dated July 8, 1633 AD. The number of Javanese year is always at odds 512 of the number of Hijri year (Arief, 2007).

This research tries to reveal the contribution of Sultan Agung Mataram's thoughts on Islamic Javanese calendar, the differences of Islamic Javanese calendar with Hijri calendar (lunar system) and Syamsiyyah (solar system) and Sultan Agung's efforts in applying Javanese Islamic calendar to Javanese society at that time.

\section{Literature Review}

There are several books that talk about Sultan Agung, but they are different from the study in this article. Some of the studies that have been done are as follows:

The work of Pogadaev, V.A entitled Sultan Agung (1591 - 1645): The Ruler of the Javanese Kingdom; Kris the Sacred Weapon of Java; On the Pirates Ship. This book tells about the biography of Sultan Agung, his governmental system, the development and expansion done by Sultan Agung to several areas, including his contrariness to the VOC in Jakarta (Pogadaev, 1998).

Purwadi wrote Sejarah Raja-Raja Jawa. He reviews the biography of Javanese kings ranging from Majapahit, Demak, Pajang, to Mataram. One of the kings discussed in the book is Sultan Agung. In his opinian, Sultan Agung is one of the greatest kings in Java, especially Mataram. In the era of Sultan Agung, Mataram progressed in politics, agriculture, culture, education, and war technology. In $\mathrm{n}$ addition, the power of Mataram, under his reign, extended to Palembang in Sumatra and Ternate (Purwadi, 2007).

The next book is Moedjianto with Konsep Kekuasaan Jawa: Penerapannya oleh Raja-Raja Mataram. This book explains the concept of power and its application by the kings of Islamic Mataram. There is a model of power adjacent to religion, even making Islam the basis of legitimacy, such as one by Sultan Agung. Sultan Agung's model of power is 'close to and supported by the scholars. This book also explains the expansion of the kings of Islamic Mataram (Moedjianto, 1987).

The Next book is Tanojo R's work entitled Primbon Djawa: Sabda Pandita Ratu. He describes the Java primrose (primbonjawa) derived from the calendar science of Sultan Agung. There are weton and saparan, i.e., days and months calculated based on the counts of Javanese Islamic calendar of Sultan Agung. This work actually talks about the calendar created by Sultan Agung, but from the side of the primbon, the counts of days is contained in the days of saparan and one's weton (Tanojo, 1962).

Handayani wrote Sistem Pemerintahan Kerajaan Mataram Islam. She explains the governmental system of Islamic Mataram kingdom from PanembahanSenopati to HamengkuBuwono IX. She discusses the governmental system of Sultan Agung, but not in detail. She only discusses that Sultan Agung has a more Islamic style of governmental system than the other kings of Mataram (Handayani, 1991).

Another work is a paper written by Muh. Sungaidi entitled Ajaran Tasawuf Sultan Agung dalam Sastra Gending. This paper reveals about the thoughts of Sufism of Sultan Agung about theology and Sufism present in the book of Sastra Gending. In the field of theology, Sultan Agung explained the unity of the three elements that make up the equilateral triangular configuration of God, man, and nature. In the field of Sufism, Sultan Agung synthesized between sharia and Sufism (Sungaidi, 2014).

Looking at the scientific publications above, there is no study on the thoughts of Sultan Agung in the Java Islamic calendar application written in detail and comprehensively.

\section{Methods}

\section{a. Type of Research}

This library research made library data as primary data. The data sources were divided into two, i.e., primary and secondary. Primary data sources used were books or works of Sultan Agung in the form of pupuh, serat, direct notes, and primbon made by Sultan Agung, such as Serat Sastra Gendhing while secondary data sources were study reports, journals and works that discussed the thoughts of Sultan Agung, especially Islamization of Sultan Agung against the people of Mataram with the decree of the Islamic Javanese Calendar.

\section{b. Approach and Method}

A historical approach was applied in this study to look at the chronological history of Sultan Agung's decree in implementing the Islamic Javanese Calendar for the Mataram society. This approach was also used to look at the other legal thoughts of Sultan Agung, such as Sufism, life, and society.

\section{Result and Discussion}

\section{a. A Short Biography of Sultan Agung}

Sultan Agung Prabu Hanyakrakusuma was born in Kotagede, Mataram, in 1593 and died in Karta (Plered, Bantul) in 1645 (Van Beek, 1990). He was the third king of Kesultanan Mataram who ruled from 1613-1645. Under his reign, Mataram grew into the largest empire in Java and Nusantara (archipelago) at the time. For his services as a fighter and culturist, Sultan Agung has been designated a national hero of Indonesia based on the decree of President No. 106/TK/1975 dated 3 November 1975. 
His original name was Raden Mas Jatmika, or also known as Raden Mas Rangsang. He was the son of Prabu Hanyakrawati and Ratu Mas Adi Dyah Banawati. His father was the second king of Mataram, while his mother was the daughter of Pangeran Benawa, the King of Pajang (Soedjipto, 2015). Sultan Agung succeeded in making Mataram a great kingdom not only built on bloodshed and violence, but also through a dignified folk culture and modern farming system (Suseso, 1985).

Besides being famous as the king of Islam with expertise in politics, he was also known to be expert in writing. Some works of Sultan Agung are Serat Sastra Gending, Serat Kakiyasaning Pangracut, Serat Mardi Utama, Serat Lamphing Gesang, Serat Banyu Bening, Kitab Ngelmu Kasampurnan, Serat Sastro Harjendro, and Serat Mardi Rahayu (Graaf, 1990). When reviewed in-depth, the works would describe two contents of meaning: first, the works on commendable behavior (akhlakulkarimah), like Serat Mardi Utama, Banyu Bening, and Serat Mardi Rahayu, and second, the works on philosophy, such as Serat Sastra Gending, Serat Kakiyasaning Pangracut, and Serat Lamphing Gesang (Sungaidi, 2014).

\section{b. Islamic Javanese Calendar of Sultan Agung}

\section{1). History of the Sultan Agung's Calendar}

The Javanese calendar which has been used by people in Central Java and Yogyakarta is the calendar created by Sultan Agung. Before using the Javanese calendar, the Sultanate of Demak, Banten, and Mataram used the Saka and Hijri calendar together. The Saka calendar derived from the Hindu-Buddhist calendar based its calculations on the solar system and the Hijri calendar based its calculations on the Moon's movement around the Earth (Lunar System) (Hariwijaya, 2002).

The reform of Javanese calendar was intended to integrate the two calendars with the spirit of combining traditions and shar'i demands, in the hope that the Islamic holidays (mawlid of the Prophet, Eid al-Fitr, and Eid al-Adha) celebrated in the Kraton Mataram (Mataram Palace) as "grebeg" could be performed on the exact day and date according to the provisions of the Hijri Calendar (Hariwijaya, 2002).

The reforms made by Sultan Agung on the previous calendar were as follows; first, the Saka calendar system which was originally a Solar system was changed into the Lunar system as in the calculation of the Hijri calendar. Second, the turn of the year began at the end of the 1554 Saka year. The year number, 1554, was maintained; Sultan Agung's Java year began on Jum'at (Friday) Legi on $1^{\text {st }}$ of Suro, year Alip, 1555, coinciding on 1 Muharram year 1043 Hijri, and 8 July 1633 AD. Third, the names of the months in the Saka year were changed to the name of the month as in the Hijri calendar. Fourth, the odd months were set at 30 days, while the even months were 29 days (except the Besar month in the long year/wuntu plus one day into rounding up 30 days). Fifth, the market days (Legi, Pahing, Pon, Wage, Kliwon) were maintained. Sixth, the determination of leap year in Javanese calendar was different from Hijri calendar. In the Javanese calendar, 1 windu, which is 8 years, was considered as a cycle that had 3 leap years, i.e., the years with the order of the $3^{\text {rd }}, 5^{\text {th }}$, and $8^{\text {th }}$. The Hijri calendar used a 30-year cycle, with leap year as the year in sequence to $2^{\text {nd }}, 5^{\text {th }}, 7^{\text {th }}, 10^{\text {th }}, 13^{\text {th }}, 16^{\text {th }}, 18^{\text {th }}$, $21^{\text {st }}, 24^{\text {th }}, 26^{\text {th }}$, and $29^{\text {th }}$. Seventh, in every 120 years there was a change of the kurup (Hariwijaya, 2002).

\section{2). The Islamic Javanese Calendar System}

Javanese and hijri calendar systems had similarities that referred to the lunar circulatory system when rounding the Earth (kamariah). The difference was that 1 year in hijri calendar had 354 days 8 hours 48 minutes or 354 11/30 days, while the Java calendar had 354 days 9 hours or 354 3/8 days (Hollander, 1951). In order that every new year of hijriyah and Java could be simultaneous (1 Muharram and 1 Suro), an adjustment that takes 120 years should be calculated. Since 1555 of Java calendar until now, it has be a change of a 120-year era for 4 times (asapon) (Hanbali, 2011).

Although both used Lunar as a benchmark in the calendar, the Javanese calendar differed from the Hijri calendar in deciding the short year for 354 days (basithoh in Hijri and wastu in Java) and the days in a year for 355 days (kabisah in Hijri and wuntu in Java) (Arfisiliana, n.d).

In the Hijri calendar, the determination of short and long year was based on a cycle period consisting of 30 years, while the Javanese calendar had a cycle period of 8 years. In the Hijri calendar including the long year was the year $2,5,7,10,13,16,18,21,24,26$, and 29 while in the Javanese calendar, the long year fell in the $2^{\text {nd }}, 5^{\text {th }}$, and $8^{\text {th }}$ (Musyarof, 2006). 


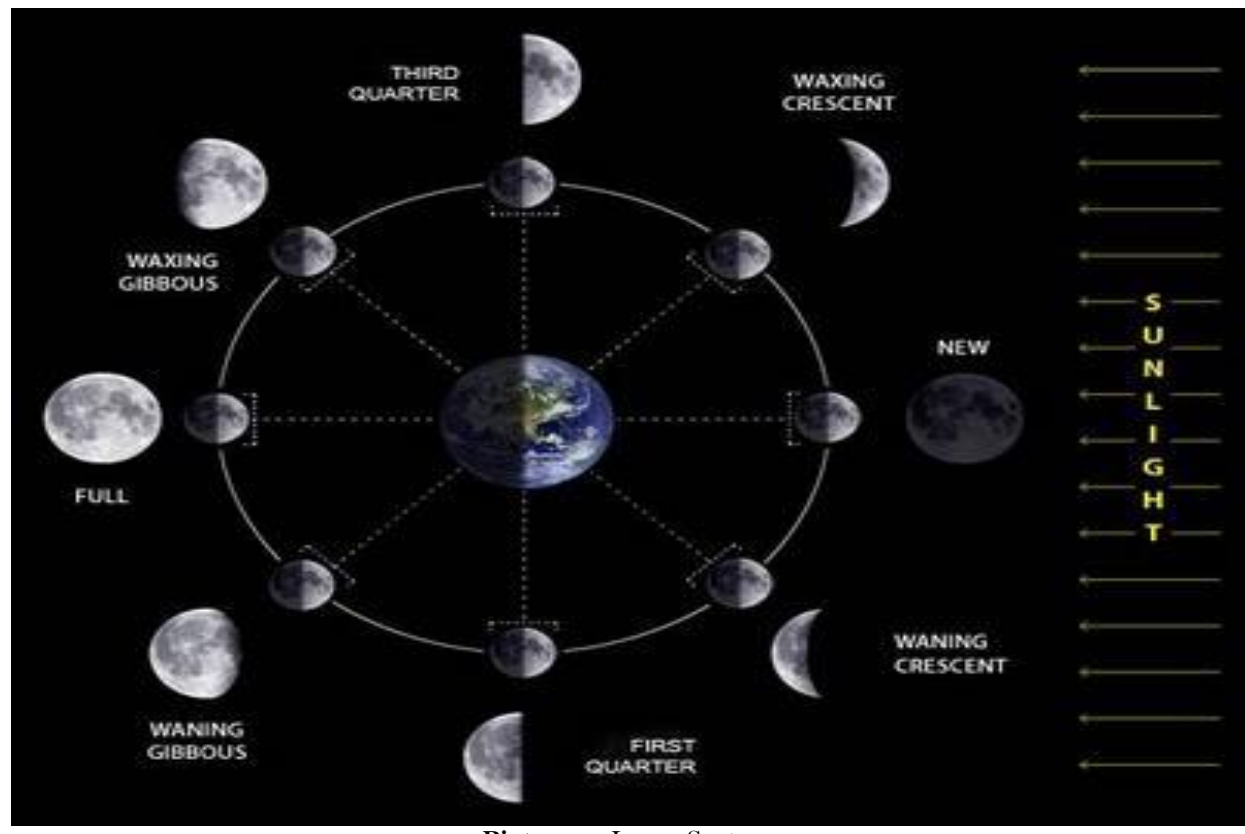

Picture-1. Lunar System.

\section{3). Rangkapan of Islamic Javanese Calendar System}

Rangkapan is components in Java calendar which include, among others, month (wulan/sasi), day (dinten), market (pasaran), wuku, and name of year. In Javanese culture, each rangkapan had its own neptu and character, used by the Javanese to show the character of the time in question (Aliy, 1977).

1. Name of the Month.

\begin{tabular}{l|l|l|l}
\hline Name of the Month & Number of Days & Neptu & Character \\
\hline Suro & 30 & 7 & Having many unfortunate events \\
\hline Sapar & 29 & 2 & Good, Understated \\
\hline Mulud & 30 & 3 & Easily having unfortunate events \\
\hline BakdaMulut & 29 & 5 & Being safe on everything \\
\hline JumadilAwal & 30 & 6 & Frequently being physically sick \\
\hline JumadilAkhir & 29 & 1 & Having parents' blessing \\
\hline Rejeb & 30 & 2 & Having many problems \\
\hline Ruwah & 29 & 4 & Being safe, having to be careful \\
\hline Poso & 30 & 5 & Having lots of luck and fortune \\
\hline Sawal & 29 & 7 & Possessing bad or evil intentions \\
\hline Dulkangidah & 30 & 1 & Being loved by the loved ones \\
\hline Besar & $29 / 30$ & 3 & Being priority, safe, good \\
\hline
\end{tabular}

\section{4). Dinten (days)}

The calculation of the alternation of days according to the community in Kasultanan Mataram (Yogyakarta/part of Java island) began after maghrib (dusk). It was in contrast to Western societies who counted the alternation of days starting at $12 \mathrm{am}$. However, the number of days was still the same seven days. The name used was the name of the days on the Hijri calendar adapted to the Javanese tongue. Each day had its neptu and character not the same from one to another. The all seven days, and their neptu and character, are illustrated in the table below.

\begin{tabular}{l|l|l}
\hline Day & Neptu & Character \\
\hline Ahad & 5 & good, good at birth, easy to imitate \\
\hline Senin & 4 & good at everything done \\
\hline Selasa & 3 & Not easy to believe \\
\hline Rabu & 7 & what is done is according what is said \\
\hline Kamis & 8 & like to think, criticize/praise \\
\hline Jum'at & 6 & always pure and clean \\
\hline Sabtu & 9 & having many wills, greedy, like to praise good stuff \\
\hline
\end{tabular}




\section{5). Market Day (Pasaran)}

Market days often called pancawara already existed before the Hindus came in the Nusantara. The number of the market days was five. Each market day had its own neptu and character believed to be influential in human life, including on the nature of the child born on that day. The all five days and their neptu and the nature of its character are as follows: (Arfisiliana, n.d).

\begin{tabular}{l|l|l}
\hline Pasaran & Neptu & Character \\
\hline Kliwon & 8 & Smooth-talking, dominant \\
\hline Legi & 5 & Dominant, rich, helpful, all \\
\hline Pahing & 9 & Like what is possessed by other people, like what he/she sees \\
\hline Pon & 7 & Like to showthe wealth off \\
\hline Wage & 4 & Strong determination or tough-minded \\
\hline
\end{tabular}

\section{6). Pranatamangsa}

Pranatamangsa in Javanese society had been used for more 2,000 years ago. It wasbased on solar movement used as guidance in farming activities and disaster preparedness (drought, disease outbreaks, crop attacks, or floods) that might arise at certain times (Hanbali, 2011).

Pranatamangsa had a cosmographic background ("the measurement of the positions of celestial bodies"), the knowledge mastered by the Austronesians as a guide for marine navigation as well as cultural ritual activities. Because the solar movement in a year caused a change of seasons, Pranatamangsa also had a number of climatological identifiers (Behrent, 1989).

Climatologically, pranatamangsa collected information on the changing seasons and the times that applied to the Nusantara affected by the monsoon, which in turn also controlled by the solar movement. The beginning of the rainy and dry season and the various physical signs described as pranatamanggsa was generally parallel to the results of climatological observations. The disadvantage of pranatamanggsa was that it did not describe variations that might occur in certain years. In addition, there were a number of provisions on pranatamanggsa more closely related to the horoscope aspect, so it tended to be illogical (Hanbali, 2011).

\section{Conclusions}

Sultan Agung is the creator of the Islamic Javanese Calendar which is a merger of the Saka and Hijri Calendar. For the sake of the dissemintaed Islamic Javanese calendar throughout the territory of Mataram at that time, Sultan Agung issued a Decree and the Regulation that required the whole society to use a new calendar, the Islamic Javanese Calendar, and no longer use the Saka Calendar derived from Hindu-Buddhist Religion.

Islamic Javanese Calendar created by Sultan Agung is a combined Calendar between Saka and Hijri Calendar. The Islamic Javanese calendar follows the Hijri calendar, but the year number of 1555 was maintained. Therefore, the date of 1 Muharram 1043 Hijri was 1 Muharam 1555 Java, which falls on Jum'at Legi (Sweet Friday) on July 8, 1633 AD.

\section{References}

Aliy, C. (1977). The lesson of reckoning is to find out the dates of Javanese Islam, Hijri, and Christianity. Semarang: Ramadan.

Aminudin, K. (2005). Archeological sunan giri: The figure of acculturation of original Indonesian culture, Hindhu-Buddhism and century Islam 15-16. Surabaya: Unesa University Press.

Arfisiliana, A. N. (n.d). Exploring the treasures of astronomy of the archipelago through the Javanese calendar and pranatamangsa. Papers, Bandung: Bandung Technology Institute.

Arief, G. (2007). Sultan Agungungokrokusumo', an encyclopedia of national heroes. Jakarta: Punctuation.

Behrent, T. (1989). Kratonand cosmos in traditional java. Paris: Archipel.

Brotodiningrat. (1978). The meaning of Kraton Yogyakarta. Yogyakarta: Yogya Kraton Museum.

Gamal, K. (2011). Indonesian atlas atlas. Yogyakarta: Quantum Science.

Graaf, H. J. D. (1990). The culmination of mathematical power: The politics of expansion of the great Sultan. Jakarta: Grafitipers Librar.

Hanbali, S. (2011). Almanacs throughout the history of the Christian, Hijri, and Javanese calendar systems (1st ed.). Semarang: Postgraduate Program of IAIN Walisongo Semarang.

Handayani. (1991). The system of Islamic Kingdom government. Jember: Ministry of Education and Culture of the Republic of Indonesia.

Hariwijaya, I. K. (2002). Yogyakarta: Tidal Wave.

Hollander, H. G. D. (1951). Celestial science, Terj. I made Sugita. Jakarta: J.B. Wolters.

Moedjianto. (1987). The concept of Javanese power: Its application by the Kings of Mataram. Yogyakarta: Kanisius.

Musyarof, I. (2006). Javanese Islam. Yogyakarta: Tugu Publisher.

Pogadaev, V. A. (1998). Sultan Agung (1591 - 1645): The ruler of the Javanese Kingdom; Kris - the sacred weapon of Java; on the pirates ship. Moscow: Znanie.

Purwadi. (2007). History of Javanese kings. Yogyakarta: Media Science. 
Soedjipto, A. (2015). Soedjipto, A. (2015). The most complete book of Mataram history: The ins and outs of the founding of the Sultanate of Yogyakarta and Surakarta Surakarta. Yogyakarta: Saufa.

Sungaidi, M. (2014). The teachings of the great Sultan of Sufism in literary gending. Jakarta: UIN Syarif.

Suseso, F. M. (1985). Javanese ethics. Jakarta: Gramedi.

Tanojo, R. (1962). Primbon Djawa: Word of the queen's goddess. Surakarta: Student TB.

Van Beek, A. (1990). Images of Asia: Life in the Javanese Kraton. Singapore: Oxford University Press. 